Article

\title{
SAP0-34 synthesized with $n$-butylamine as a template and its catalytic application in the methanol amination reaction
}

\author{
Yuyan Qiao a,b, Pengfei Wu a,b, Xiao Xiang a,b, Miao Yang a, Quanyi Wang a, Peng Tian a,*, \\ Zhongmin Liu a,\# \\ a National Engineering Laboratory for Methanol to Olefins, Dalian Institute of Chemical Physics, Chinese Academy of Sciences, Dalian 116023, Liaoning, \\ China \\ b University of Chinese Academy of Sciences, Beijing 100039, China
}

\section{A R T I C L E I N F}

Article history:

Received 28 November 2016

Accepted 25 December 2016

Published 5 March 2017

\section{Keywords:}

SAPO-34 molecular sieve

n-Butylamine

Primary amine

Synthesis

High temperature

Methanol amination

\begin{abstract}
A B S T R A C T
SAPO-34 was synthesized with $n$-butylamine (BA) as a template for the first time. Crystallization temperature and initial Si amount were important factors leading to successful syntheses. Lamellar AlPO-kanemite tends to form as the major phase or as an impurity of SAPO-34 at lower crystallization temperatures, though a higher initial Si amount may offer a positive effect on the crystallization of SAPO-34 that mitigates the low temperature. Higher temperature $\left(240{ }^{\circ} \mathrm{C}\right)$ can effectively suppress the generation of lamellar materials and allow the synthesis of pure SAPO-34 with a wider range of $\mathrm{Si}$ incorporation. The crystallization processes at 200 and $240{ }^{\circ} \mathrm{C}$ were investigated and compared. We used the aminothermal method to synthesize SAPO-34-BA at $240{ }^{\circ} \mathrm{C}$ and also found $n$-propylamine is a suitable template for the synthesis of SAPO-34. The SAPO-34-BA products were characterized by many techniques. SAPO-34-BA has good thermal stability, crystallinity and porosity. BA remained intact in the crystals with $\sim 1.8$ BA molecule per chabazite cage. The catalytic performance of SAPO-34 was tested in the methanol amination reaction, which showed high methanol conversion and selectivity for methylamine plus dimethylamine under the conditions investigated, suggesting that this material is a good candidate for the synthesis of methylamines.
\end{abstract}

(C) 2017, Dalian Institute of Chemical Physics, Chinese Academy of Sciences. Published by Elsevier B.V. All rights reserved.

\section{Introduction}

Silicoaluminophosphate (SAPO) molecular sieves, first reported by the scientists at Union Carbide Corporation in 1984, are a class of important inorganic microporous materials [1,2]. Among them, SAPO-34 is the most important member because of its successful application in the commercial methanol-to-olefins (MTO) process in 2010 [3-6]. Investigation of the synthesis and physicochemical properties of SAPO-34 molecu- lar sieves remains of continuous interest. Many methods have been developed to synthesize SAPO-34, such as hydrothermal, solvothermal, dry-gel conversion, and solvent-free syntheses [7-11]. The presence of an organic template is necessary for all the methods to prepare SAPO molecular sieves, and the template has a crucial impact on the physicochemical properties of the products because of its structure-directing, charge-compensating and space-filling roles in the crystallization process [12-15]. Many organic amines have been used as

\footnotetext{
* Corresponding author. Tel: +86-411-84379218; Fax: +86-411-84691570; E-mail: tianpeng@dicp.ac.cn

\# Corresponding author. Tel: +86-411-84379998; Fax: +86-411-84691570; E-mail: liuzm@dicp.ac.cn

This work was supported by the National Natural Science Foundation of China(21676262, 21476228, 21506207) and the Key Research Program of Frontier Sciences of CAS (QYZDB-SSW-JSC040).

DOI: 10.1016/S1872-2067(17)62775-X| http://www.sciencedirect.com/science/journal/18722067 | Chin. J. Catal., Vol. 38, No. 3, March 2017
} 
templating agents to synthesize SAPO-34 [16-20]. The elemental composition, local microscopic structure and morphology of SAPO-34 may change with the use of different templates. Accordingly, the catalytic performance and adsorption properties of the materials obtained may be different [15-20].

The primary amine $n$-butylamine (BA) has been used to synthesize lamellar AlPO-kanemite [21]. Lamellar AlPO-kanemite can be transformed to SAPO-34 by adding a silica source and hexamethyleneimine (HMI) into the synthetic system under hydrothermal conditions [22]. SAPO-34 is co-templated by HMI and BA and pure SAPO-34 is synthesized in over a relatively narrow range of the $\mathrm{SiO}_{2} / \mathrm{Al}_{2} \mathrm{O}_{3}$ molar ratio in the initial gel [22]. To the best of our knowledge, there is no report on the synthesis of SAPO-34 with a single BA template.

In this paper, we report the synthesis, characterization, and catalytic application of SAPO-34 with BA as a template for the first time. The importance of initial silica amount and crystallization temperature on the SAPO-34 synthesized was investigated. The hydrothermal crystallization process at two different crystallization temperatures was examined in order to better understand/control the synthesis system with a BA template. The physicochemical properties of the BA-templated SAPO-34 were characterized with powder X-ray diffraction (XRD), X-ray fluorescence (XRF), scanning electron microscopy (SEM), nuclear magnetic resonance (NMR), thermogravimetry-differential thermal analysis (TG-DTA), ammonia temperature-programmed desorption ( $\mathrm{NH}_{3}-\mathrm{TPD}$ ) and $\mathrm{N}_{2}$ physisorption. The catalytic performance of the samples was tested in the methanol amination reaction.

\section{Experimental}

\subsection{Synthesis}

Organic amines used as templates in the syntheses were n-butylamine (BA, $99.5 \mathrm{wt} \%), n$-propylamine (PA, $99.5 \mathrm{wt} \%$ ), and cyclohexylamine (CyHA, 99.5 wt\%). Pseudoboehmite $(67.5$ wt\%), phosphoric acid (85 wt\%), silica sol (31 wt \%), tetraethyl orthosilicate (TEOS), and fume silica were used as inorganic precursors.

A typical hydrothermal synthesis procedure was as follows: the organic amine, Si source, pseudoboehmite, phosphoric acid and distilled water were added sequentially into a stainless steel autoclave. The typical molar composition of the gel was 2.0BA:0.8 $\mathrm{SiO}_{2}: 1.0 \mathrm{Al}_{2} \mathrm{O}_{3}: 0.8 \mathrm{P}_{2} \mathrm{O}_{5}: 50 \mathrm{H}_{2} \mathrm{O}$. The mixture was stirred until homogeneous, the autoclave sealed quickly and placed in a rotation oven. The gel was heated to the desired temperature under rotation and held for a certain time. After crystallization, the as-synthesized sample was obtained by centrifugal separation, washing and drying in air at $120^{\circ} \mathrm{C}$. The catalyst was prepared by heating the sample in air at $600{ }^{\circ} \mathrm{C}$ for $2 \mathrm{~h}$ in a muffle furnace to remove the organic template.

\subsection{Characterization}

The XRD data was recorded on a PANalytical X'Pert PRO X-ray diffractometer with $\mathrm{Cu} K \alpha$ radiation $(\lambda=1.54059 \AA)$ op- erating at $30 \mathrm{~mA}$ and $40 \mathrm{kV}$. Sample morphology was determined by SEM on a Hitachi TM3000 microscope. The compositions of samples were determined with a Philips Magix-601 XRF spectrometer. Textural properties of the calcined samples were determined by $\mathrm{N}_{2}$ adsorption-desorption at $-196^{\circ} \mathrm{C}$ on a Micromeritics ASAP 2020 system. The total surface area was calculated based on the Brunauer-Emmett-Teller (BET) equation. The micropore volume and surface area were evaluated using the $t$-plot method. Mesopore volume and surface area were evaluated from the adsorption isotherm by the Barrett-Joyner-Halenda (BJH) method. All the solid state NMR experiments were performed on a Bruker Avance III 600 spectrometer equipped with a $14.1 \mathrm{~T}$ wide-bore magnet. The resonance frequencies were set at 150.9, 156.4, 242.9, and 119.2 $\mathrm{MHz}$ for ${ }^{13} \mathrm{C},{ }^{27} \mathrm{Al},{ }^{31} \mathrm{P}$, and ${ }^{29} \mathrm{Si}$, respectively. Chemical shifts were referenced to $1.0 \mathrm{~mol} / \mathrm{L} \mathrm{Al}\left(\mathrm{NO}_{3}\right)_{3}$ for ${ }^{27} \mathrm{Al}, 85 \% \mathrm{H}_{3} \mathrm{PO}_{4}$ for ${ }^{31} \mathrm{P}, 2$,2-dimethyl-2-silapentane-5-sulfonate sodium salt for ${ }^{29} \mathrm{Si}$, and adamantane for ${ }^{13} \mathrm{C}$. The $\mathrm{NH}_{3}$-TPD was carried out with Micromeritics Autochem 2920 equipment. The calcined samples (200 mg, 40-60 mesh) were activated at $650{ }^{\circ} \mathrm{C}$ for $60 \mathrm{~min}$ $\left(10{ }^{\circ} \mathrm{C} / \mathrm{min}\right)$ under He flow, then cooled and saturated with ammonia at $150{ }^{\circ} \mathrm{C}$ for $30 \mathrm{~min}$. The samples were purged with $\mathrm{He}(30 \mathrm{~mL} / \mathrm{min})$ for $30 \mathrm{~min}$ and measurements of the desorbed $\mathrm{NH}_{3}$ were performed from 100 to $700{ }^{\circ} \mathrm{C}\left(10{ }^{\circ} \mathrm{C} / \mathrm{min}\right)$ under a He flow $(30 \mathrm{~mL} / \mathrm{min})$. The TGA were recorded on a Q500 SDT thermogravimetric analyzer. In a typical measurement, a small amount (10-20 mg) of sample was heated in an $\mathrm{Al}_{2} \mathrm{O}_{3}$ crucible from ambient temperature to $800{ }^{\circ} \mathrm{C}$ at a heating rate of 10 ${ }^{\circ} \mathrm{C} /$ min under a stream of air at a constant flow rate of 100 $\mathrm{mL} / \mathrm{min}$.

\subsection{Catalyst evaluation}

The methanol amination reaction was carried out with a fixed-bed quartz tubular reactor at atmospheric pressure. Typically, $300 \mathrm{mg}$ of calcined SAPO-34 sample (40-60 mesh) was loaded in the reactor and activated under a He flow at $500{ }^{\circ} \mathrm{C}$ for $1 \mathrm{~h}$, then the reactor was cooled to the reaction temperature $\left(350^{\circ} \mathrm{C}\right)$. The reaction was carried out by feeding the reactor with a 2:1 mixture (on mole basis) of ammonia and methanol diluted in helium. Methanol was fed into the reactor by passing the carrier gas (He, $25.3 \mathrm{~mL} / \mathrm{min}$ ) through a methanol saturator maintained at $10{ }^{\circ} \mathrm{C}$. The weight hourly space velocity (WHSV) of methanol was $0.813 \mathrm{~h}^{-1}$. The products were analyzed by an online gas chromatograph (Agilent GC 7890N) equipped with a flame ionization detector and CP-Volamine column.

\section{Results and discussion}

\subsection{Effect of synthesis conditions}

\subsubsection{Effect of silica amount and silica source}

The effect of the initial silica amount on the SAPO-34 synthesis using silica sol as the Si source was investigated by fixing the other synthetic conditions. Table 1 shows the detailed gel compositions, crystallization conditions and product composi- 
Table 1

Influence of silica amount and silica source on SAPO-34 synthesis.

\begin{tabular}{|c|c|c|c|c|c|}
\hline Sample & Silica source & $n^{*}$ & Product & Yield (\%) & Product composition \\
\hline 0 & - & 0.0 & kanemite & 95 & - \\
\hline 1 & silica sol & 0.2 & SAPO-34 + kanemite & 91 & $\mathrm{Si}_{0.039} \mathrm{Al}_{0.525} \mathrm{P}_{0.436}$ \\
\hline 2 & silica sol & 0.4 & SAPO-34 + kanemite & 89 & $\mathrm{Si}_{0.098} \mathrm{Al}_{0.508} \mathrm{P}_{0.394}$ \\
\hline 3 & silica sol & 0.6 & SAPO-34 & 82 & $\mathrm{Si}_{0.161} \mathrm{Al}_{0.492} \mathrm{P}_{0.347}$ \\
\hline 4 & silica sol & 0.8 & SAPO-34 & 83 & $\mathrm{Si}_{0.207} \mathrm{Al}_{0.472} \mathrm{P}_{0.321}$ \\
\hline 5 & silica sol & 1.2 & SAPO-34 & 83 & $\mathrm{Si}_{0.244} \mathrm{Al}_{0.453} \mathrm{P}_{0.303}$ \\
\hline 6 & silica sol & 1.4 & SAPO-34 & 84 & $\mathrm{Si}_{0.266} \mathrm{Al}_{0.441} \mathrm{P}_{0.293}$ \\
\hline 7 & silica sol & 1.6 & SAPO-34 + amorphous $\mathrm{SiO}_{2}$ & 86 & $\mathrm{Si}_{0 . .300} \mathrm{Al}_{0.420} \mathrm{P}_{0.280}$ \\
\hline 8 & TEOS & 0.8 & SAPO-34 & 82 & $\mathrm{Si}_{0.198} \mathrm{Al}_{0.477} \mathrm{P}_{0.325}$ \\
\hline 9 & fume silica & 0.8 & SAPO-34 & 83 & $\mathrm{Si}_{0.200} \mathrm{Al}_{0.445} \mathrm{P}_{0.335}$ \\
\hline 10 & fume silica & 1.4 & SAPO-34 & 83 & $\mathrm{Si}_{0.293} \mathrm{Al}_{0.430} \mathrm{P}_{0.277}$ \\
\hline
\end{tabular}

${ }^{*} \mathrm{SiO}_{2} / \mathrm{Al}_{2} \mathrm{O}_{3}$ molar ratio in the initial gel. All the syntheses were carried out at $200{ }^{\circ} \mathrm{C}$ for $24 \mathrm{~h}$ under rotation. Initial molar compositions were as follows: $\mathrm{BA}: \mathrm{Al}_{2} \mathrm{O}_{3}: \mathrm{P}_{2} \mathrm{O}_{5}: \mathrm{SiO}_{2}: \mathrm{H}_{2} \mathrm{O}=2.0: 1.0: 0.8: n: 50$.

tions. Figs. 1 and 2 display the XRD patterns and SEM images of the as-synthesized samples. Lamellar material AlPO-kanemite was obtained as the only product when a silica source was omitted in the initial gel. After inclusion of a small amount of silica sol, SAPO-34 starts to appear and gradually becomes the dominant product with increasing amounts of silica at the expense of AlPO-kanemite, suggesting the positive effect of silica on inhibiting the formation of lamellar material and facilitating the generation of SAPO-34. Pure SAPO-34 was obtained once the silica amount reached 0.6 equivalents relative to the pseudoboehmite or higher. However, greater Si amounts in the initial gel $(n=1.6)$ resulted in the presence of an amorphous phase because of the unreacted silica residues, implying the capacity limitation of silica incorporation into the framework of BA-templated SAPO-34. The solid yields and elemental compositions of the samples are shown in Table 1. All samples tem-

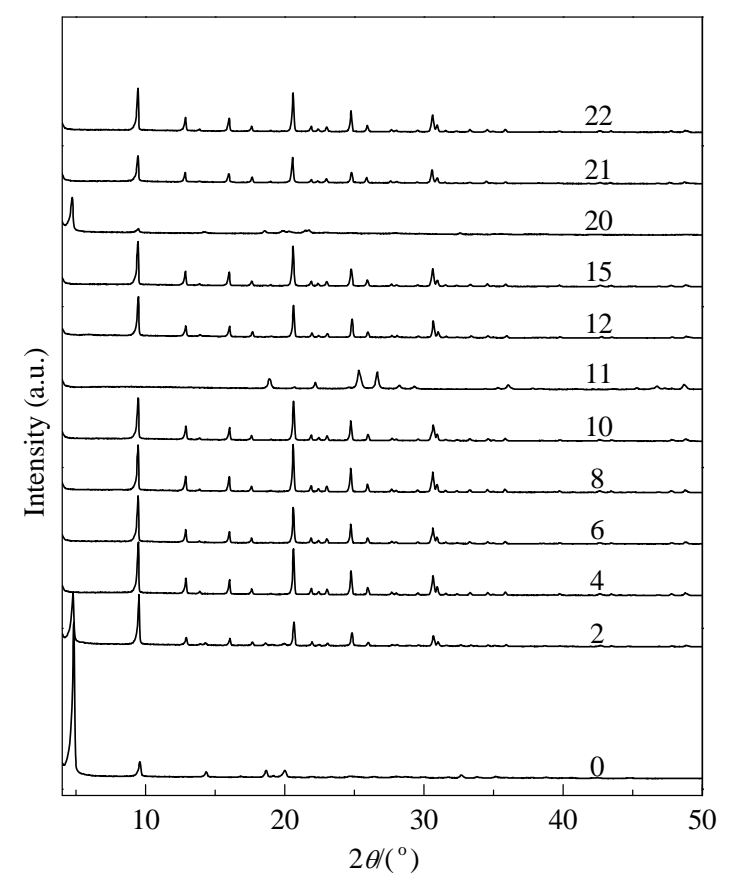

Fig. 1. XRD patterns of the as-synthesized samples. plated by BA have high solid yields of $>80 \%$. SAPO-34 products synthesized under hydrothermal conditions have characteristically high silica content, with Si molar concentration varying from 0.161 to 0.266 . The SEM image of Sample 4 shows rhombohedra crystals with a size range of about 5-10 $\mu \mathrm{m}$ (Fig. 1).

The effect of the Si source on the syntheses was also investigated. Both fumed silica and TEOS gave similar synthetic results as silica sol. SAPO-34 synthesized with fumed silica has relatively high Si content (Table 1) and small crystal sizes (Fig. 1) as compared with SAPO-34 prepared with the other two silica sources.
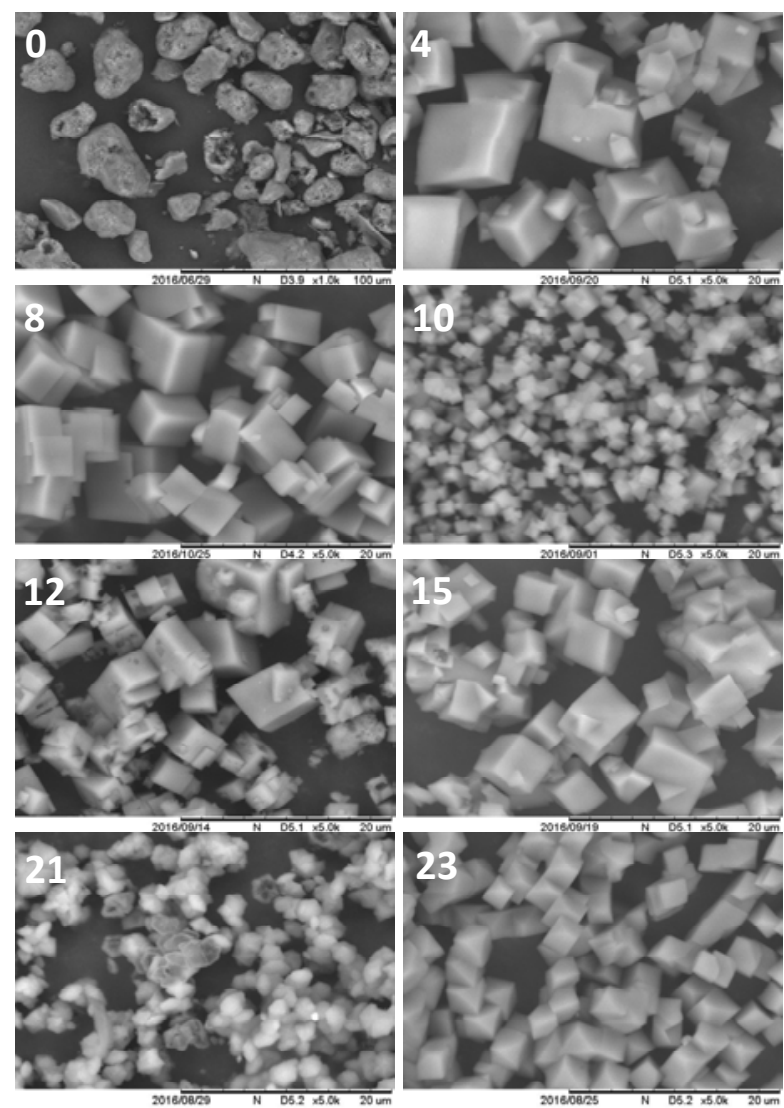

Fig. 2. SEM images of the as-synthesized samples. 
Table 2

Influence of crystallization temperature on SAPO-34 synthesis.

\begin{tabular}{|c|c|c|c|c|c|c|}
\hline Sample & $n^{*}$ & $T\left({ }^{\circ} \mathrm{C}\right)$ & $t(\mathrm{~h})$ & Product & Yield (\%) & Product composition \\
\hline$\overline{11}$ & 0.0 & 240 & 24 & dense phase & 50 & - \\
\hline 12 & 0.2 & 240 & 3 & SAPO-34 & 52 & $\mathrm{Si}_{0.089} \mathrm{Al}_{0.537} \mathrm{P}_{0.374}$ \\
\hline 13 & 0.4 & 240 & 8 & SAPO-34 & 74 & $\mathrm{Si}_{0.106} \mathrm{Al}_{0.501} \mathrm{P}_{0.393}$ \\
\hline 14 & 0.6 & 240 & 24 & SAPO-34 & 83 & $\mathrm{Si}_{0.153} \mathrm{Al}_{0.480} \mathrm{P}_{0.367}$ \\
\hline 15 & 0.8 & 240 & 24 & SAPO-34 & 84 & $\mathrm{Si}_{0.189} \mathrm{Al}_{0.463} \mathrm{P}_{0.348}$ \\
\hline 16 & 1.2 & 240 & 24 & SAPO-34 & 84 & $\mathrm{Si}_{0.245} \mathrm{Al}_{0.432} \mathrm{P}_{0.323}$ \\
\hline 17 & 1.4 & 240 & 24 & SAPO-34 + amorphous $\mathrm{SiO}_{2}$ & 86 & $\mathrm{Si}_{0.308} \mathrm{Al}_{0.400} \mathrm{P}_{0.292}$ \\
\hline 18 & 0.4 & 160 & 48 & kanemite & 93 & - \\
\hline 19 & 0.8 & 160 & 48 & kanemite & 94 & - \\
\hline 20 & 1.2 & 160 & 48 & kanemite & 94 & - \\
\hline
\end{tabular}

${ }^{*} \mathrm{SiO}_{2} / \mathrm{Al}_{2} \mathrm{O}_{3}$ molar ratio in the initial gel. Initial molar compositions were as follows: $\mathrm{BA}: \mathrm{Al}_{2} \mathrm{O}_{3}: \mathrm{P}_{2} \mathrm{O}_{5}: \mathrm{SiO}_{2}: \mathrm{H}_{2} \mathrm{O}=2.0: 1.0: 0.8: n: 50$. Silica sol was used as the Si source.

\subsubsection{Effect of crystallization temperature}

The effect of crystallization temperature on the syntheses was investigated (Table 2). Only AlPO-kanemite was obtained at $160{ }^{\circ} \mathrm{C}$, even with a high silica feed. Raising the crystallization temperature to $240{ }^{\circ} \mathrm{C}$ in the absence of silica formed a dense phase instead of AlPO-kanemite. Pure SAPO-34 was readily produced when the $\mathrm{SiO}_{2} / \mathrm{Al}_{2} \mathrm{O}_{3}$ molar ratio in the initial gel was increased to 0.2 or higher. This is very different from the syntheses at relatively low temperatures, as no molecular sieve products formed at $160{ }^{\circ} \mathrm{C}$ and higher Si content in the initial gel was required to achieve pure SAPO-34 at $200{ }^{\circ} \mathrm{C}$. The results are reasonable considering that lamellar materials generally have worse thermal stability than SAPO molecular sieves and higher crystallization temperatures impose negative effects on lamellar material formation. Crystallization temperature may be used to tune/optimize the crystal phase, especially for systems where lamellar material is an impurity.

Table 2 lists the elemental compositions of the products. The Si content in SAPO-34 synthesized at $240{ }^{\circ} \mathrm{C}$ varied from 0.089 to 0.245 , which is a wider range than that of SAPO-34 synthesized at $200{ }^{\circ} \mathrm{C}$. The SEM images of selected samples are given in Fig. 2. The samples present rhombohedra morphology with crystal sizes of 4-6 $\mu \mathrm{m}$, which are a little smaller than those obtained at $200^{\circ} \mathrm{C}$.

\subsection{Crystallization process of BA-templated SAPO-34}

The crystallization processes of BA-templated SAPO-34 at 200 and $240{ }^{\circ} \mathrm{C}$ were examined based on the synthetic systems of Samples 4 and 15, respectively. Table 3 shows the detailed information about the product phases, elemental compositions, and solid yields. Fig. 3 displays the SEM images of the as-synthesized samples.

Just lamellar AlPO-kanemite was generated first for the synthesis at $200{ }^{\circ} \mathrm{C}$ at the beginning of crystallization $(1 \mathrm{~h})$. The high solid yield of $60 \%$ suggests rapid and facile formation of lamellar material. The diffraction peaks arising from AlPO-kanemite become stronger after crystallization for $3 \mathrm{~h}$. SAPO-34 begins to appear and the solid yield increased to $85 \%$. Subsequently, SAPO-34 became the major phase at the expense of AlPO-kanemite. Only minor kanemite was detected after $5 \mathrm{~h}$ crystallization time and the relative crystallinity of the SAPO-34 reached $78 \%$. Extending the crystallization time further gave pure SAPO-34 and the relative crystallinity increased until the end of the crystallization. The silicon content in the products rises continuously throughout the crystallization process (Table 3), which is consistent with our previous studies [7] and suggests the relatively slow reaction rate with the Si source as compared with $\mathrm{Al}$ and $\mathrm{P}$ sources.

According to the above results, the crystallization process at

Table 3

Crystallization processes of Samples 4 and 15.

\begin{tabular}{|c|c|c|c|c|c|}
\hline Sample & $t(\mathrm{~h})$ & Product & $\mathrm{R}(\%)^{*}$ & Yield (\%) & Product composition \\
\hline $4-1 h$ & 1 & kanemite & - & 60 & - \\
\hline $4-3 h$ & 3 & Kanemite + SAPO-34 & - & 85 & $\mathrm{Si}_{0.131} \mathrm{Al}_{0.511} \mathrm{P}_{0.358}$ \\
\hline $4-5 h$ & 5 & SAPO-34 + kanemite & 78 & 81 & $\mathrm{Si}_{0.174} \mathrm{Al}_{0.496} \mathrm{P}_{0.330}$ \\
\hline $4-12 \mathrm{~h}$ & 12 & SAPO-34 & 87 & 82 & $\mathrm{Si}_{0.192} \mathrm{Al}_{0.483} \mathrm{P}_{0.325}$ \\
\hline 4 & 24 & SAPO-34 & 100 & 83 & $\mathrm{Si}_{0.207} \mathrm{Al}_{0.472} \mathrm{P}_{0.321}$ \\
\hline $15-0 \mathrm{~h}$ & 0 & amorphous & - & 26 & - \\
\hline $15-1 \mathrm{~h}$ & 1 & SAPO-34 & 83 & 81 & $\mathrm{Si}_{0.142} \mathrm{Al}_{0.489} \mathrm{P}_{0.369}$ \\
\hline $15-3 h$ & 3 & SAP0-34 & 100 & 83 & $\mathrm{Si}_{0.172} \mathrm{Al}_{0.470} \mathrm{P}_{0.358}$ \\
\hline $15-8 \mathrm{~h}$ & 8 & SAPO-34 & 100 & 83 & $\mathrm{Si}_{0.178} \mathrm{Al}_{0.467} \mathrm{P}_{0.355}$ \\
\hline 15 & 24 & SAPO-34 & 100 & 84 & $\mathrm{Si}_{0.189} \mathrm{Al}_{0.463} \mathrm{P}_{0.348}$ \\
\hline
\end{tabular}

${ }^{*}$ Relative crystallinities calculated based on the intensity of the two strongest peaks $\left(2 \theta=9.5^{\circ}\right.$ and $\left.20.5^{\circ}\right)$ in the XRD patterns of the samples. 

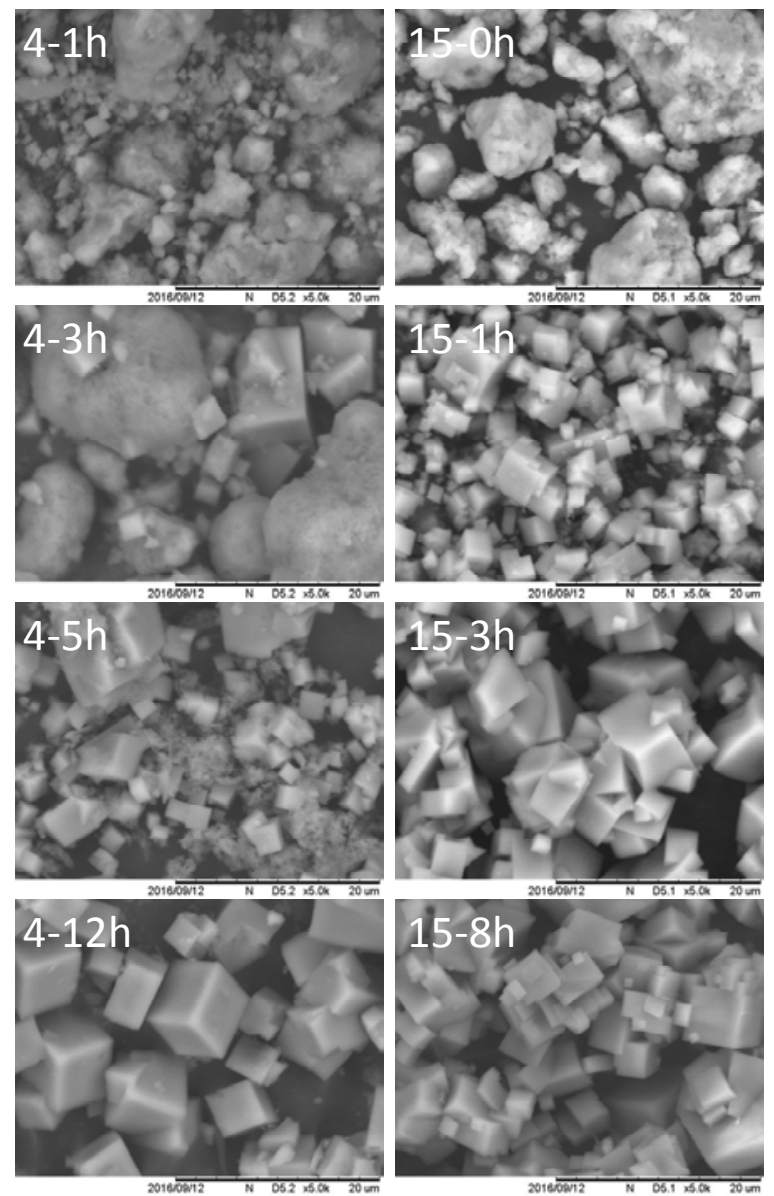

Fig. 3. SEM images of samples synthesized with different crystallization times. Left: based on the synthetic system of Sample $4\left(20{ }^{\circ} \mathrm{C}\right)$; Right: based on the synthetic system of Sample $15\left(240^{\circ} \mathrm{C}\right)$.

$200{ }^{\circ} \mathrm{C}$ can be established. AlPO-kanemite forms quickly in the initial stage of the crystallization because of its simple lamellar structure. Subsequently, SAPO-34 appears as a second phase with the participation of silica. SAPO-34 materials have higher thermodynamic stability than kanemite and the SAPO-34 products have more opportunity to survive in the synthetic gel. The growth of SAPO-34 may cause changes to gel pH and composition [18], which further prompt the dissolution of kanemite. Finally, SAPO-34 becomes the only product.

Only a small amount of amorphous materials was observed at $t=0 \mathrm{~h}$ in the product formed at $240{ }^{\circ} \mathrm{C}$. Heating the gel for 1 $\mathrm{h}$ formed pure SAPO-34 with high crystallinity (83\%) and solid yield $(81 \%)$. The relative crystallinity of the SAPO-34 product reached $100 \%$ after $3 \mathrm{~h}$ and maintained at this level until the end of the crystallization, indicating a fast crystallization rate at high temperature. Kanemite or other lamellar materials were not detected throughout the crystallization process, which confirms the suppression of the generation of lamellar phase at high temperatures. The Si content in the product also shows an increasing trend with time, consistent with the findings of the crystallization process at $200{ }^{\circ} \mathrm{C}$. The above phenomena indicate that the crystallization process at $240{ }^{\circ} \mathrm{C}$ is simple as compared with that at $200{ }^{\circ} \mathrm{C}$, which consisted of initial dissolution
Table 4

Aminothermal synthesis of CHA-type SAPO molecular sieves using BA, CHyA and PA systems.

\begin{tabular}{lcccccc}
\hline Sample & Template & $\begin{array}{c}T \\
\left({ }^{\circ} \mathrm{C}\right)\end{array}$ & $\begin{array}{c}t \\
(\mathrm{~h})\end{array}$ & Product & $\begin{array}{c}\text { Yield } \\
(\%)\end{array}$ & $\begin{array}{c}\text { Product } \\
\text { composition }\end{array}$ \\
\hline 21 & $\mathrm{PA}$ & 240 & 24 & $\mathrm{SAPO}-34$ & 68 & $\mathrm{Si}_{0.281} \mathrm{Al}_{0.460} \mathrm{P}_{0.259}$ \\
22 & $\mathrm{BA}$ & 240 & 8 & $\mathrm{SAPO}-34$ & 86 & $\mathrm{Si}_{0.201} \mathrm{Al}_{0.465} \mathrm{P}_{0.334}$ \\
23 & $\mathrm{CyHA}$ & 240 & 24 & $\mathrm{SAPO}-44$ & 90 & $\mathrm{Si}_{0.211} \mathrm{Al}_{0449} \mathrm{P}_{0.340}$ \\
\hline The & initial & molar & compositions & were & as & follows: 7R:0.8SiO
\end{tabular}

$1.0 \mathrm{Al}_{2} \mathrm{O}_{3}: 0.8 \mathrm{P}_{2} \mathrm{O}_{5}: 15 \mathrm{H}_{2} \mathrm{O}$. TEOS was used as the Si source.

of inorganic raw materials and their fast crystallization to SAPO-34.

\subsection{Aminothermal synthesis of SAPO-34 based on three primary amines}

We recently reported $[8,11]$ aminothermal synthesis as a method to synthesize SAPO molecular sieves, in which organic amines are used as both a solvent and template. The aminothermal method has shown some advantages including high yield and good methanol-to-olefins catalytic performance of the products [11,23]. Primary amines, including BA, PA, CyHA and 1,2-ethylenediamine (EDA), always lead to the formation of lamellar materials at $200{ }^{\circ} \mathrm{C}$ with the aminothermal synthesis method [9]. Herein, we investigated conducting the synthesis at the elevated temperature of $240{ }^{\circ} \mathrm{C}$ with three primary amines (BA, PA and CyHA) employed as the solvent and template. High temperature effectively inhibited the formation of lamellar materials and facilitated the synthesis of pure chabazite (CHA)-type SAPO products (Table 4), similar to those produced by the hydrothermal synthesis process. PA is a novel template for the synthesis of SAPO-34 (Figs. 1 and 2). From the elemental composition of the samples determined by XRF (Table 4), SAPO-34-PA possesses higher silicon content than SAPO-34-BA and SAPO-44-CyHA synthesized with the same initial molar composition. This is likely an effect of the smaller molecule size of PA.

\subsection{Physiochemical properties of SAPO-34 templated by BA}

The textural properties of Samples 4, 15 and 22 were characterized by nitrogen physisorption (Table 5). All of the samples have typical type I isotherms. The BET surface area and micropore volume of Sample 4 are $585 \mathrm{~m}^{2} / \mathrm{g}$ and $0.27 \mathrm{~cm}^{3} / \mathrm{g}$, respectively. The values of samples 15 and 22 are close to those of sample 4, confirming the good crystallinity and porosity of

\section{Table 5}

Textural properties of Samples 4,15 and 22.

\begin{tabular}{lccccc}
\hline Sample & $\begin{array}{c}A_{\text {BET }}{ }^{\mathrm{a}} \\
\left(\mathrm{m}^{2} / \mathrm{g}\right)\end{array}$ & $\begin{array}{c}A_{\text {mic }} \mathrm{b} \\
\left(\mathrm{m}^{2} / \mathrm{g}\right)\end{array}$ & $\begin{array}{c}A_{\text {ext }} \mathrm{c} \\
\left(\mathrm{m}^{2} / \mathrm{g}\right)\end{array}$ & $\begin{array}{c}V_{\text {mic }^{\mathrm{d}}} \\
\left(\mathrm{cm}^{3} / \mathrm{g}\right)\end{array}$ & $\begin{array}{c}V_{\text {meso }}{ } \\
\left(\mathrm{cm}^{3} / \mathrm{g}\right)\end{array}$ \\
\hline 4 & 585 & 576 & 9 & 0.27 & 0.00 \\
15 & 574 & 566 & 8 & 0.27 & 0.01 \\
22 & 592 & 585 & 7 & 0.28 & 0.02 \\
\hline
\end{tabular}

${ }^{a}$ BET surface area. ${ }^{b}$ t-plot micropore surface area. ${ }^{\mathrm{c}} \mathrm{t}$-plot external surface area. ${ }^{\mathrm{d}} \mathrm{t}$-plot micropore volume. ${ }^{\mathrm{e}} \mathrm{BJH}$ adsorption volume. 


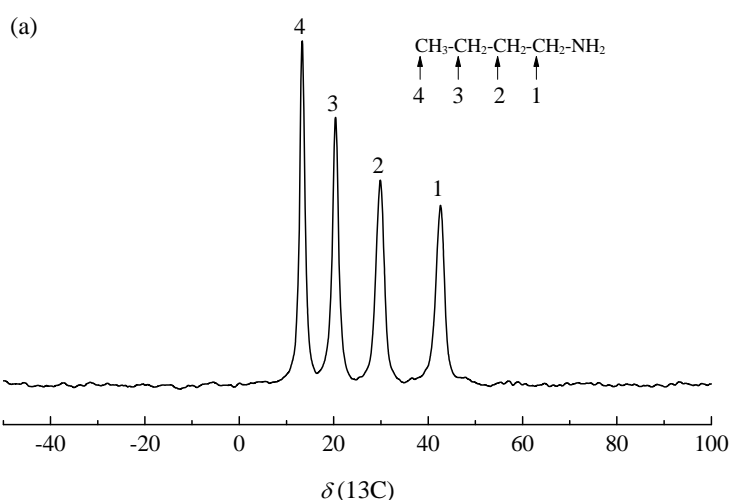

(c)

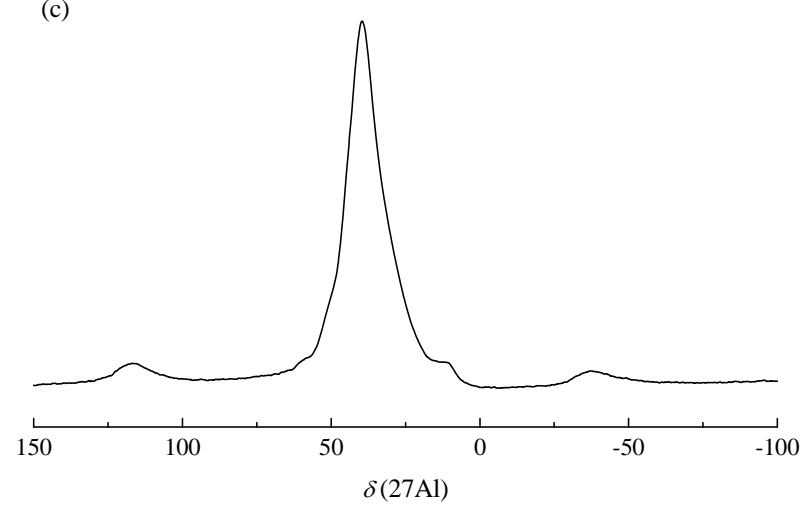

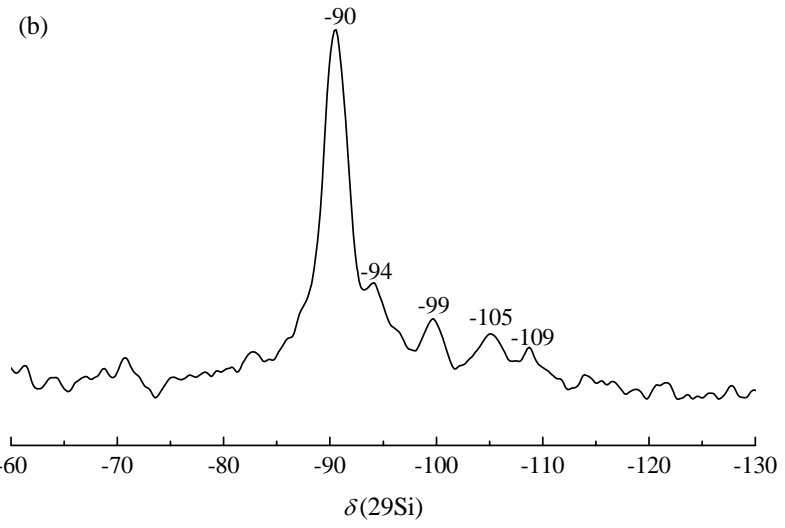

(d)

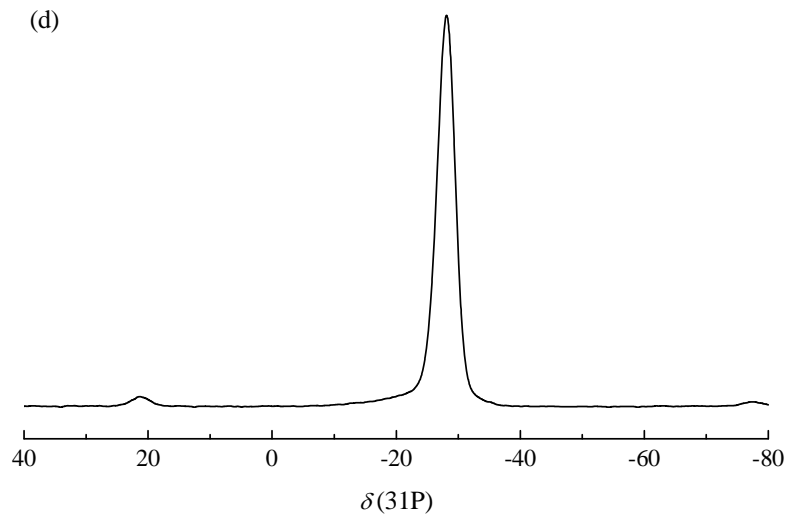

Fig. 4. ${ }^{13} \mathrm{C}(\mathrm{a}),{ }^{29} \mathrm{Si}(\mathrm{b}),{ }^{27} \mathrm{Al}(\mathrm{c})$ and ${ }^{31} \mathrm{P}(\mathrm{d}) \mathrm{MAS}$ NMR spectra of Sample 4.

the samples.

A ${ }^{13} \mathrm{C}$ MAS NMR spectrum was recorded to verify the exact template species occluded in Sample 4 (Fig. 4). The spectrum exhibits four symmetrical peaks between 50 and $10 \mathrm{ppm}$, which can be ascribed to the carbon atom directly attached to the nitrogen atoms (C1) and the other three conjoint carbon atoms in the BA molecules, respectively. This result is in good agreement with previous literature [24] and implies that BA remains intact in the SAPO-34 crystals.

The TG-DTA curve of Sample 4 is shown in Fig. 5 and the corresponding weight loss of each stage are summarized in

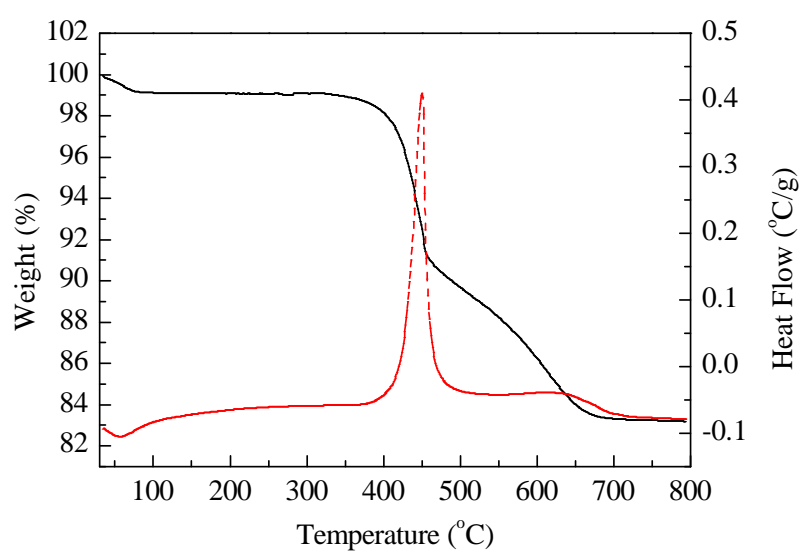

Fig. 5. TG-DTA curve of Sample 4.
Table 6. TG result shows that Sample 4 has three weight loss stages (I, II, III) in the range of $30-800{ }^{\circ} \mathrm{C}$. The first weight loss stage at $50-200{ }^{\circ} \mathrm{C}$ is an endothermic process attributed to water desorption from the sample. The second and third weight loss stages between 200 and $700{ }^{\circ} \mathrm{C}$ are strongly exothermic processes attributed to the combustion decomposition of the template and organic residue, respectively. There is no weight loss and exothermic peak associated with structural collapse until $800{ }^{\circ} \mathrm{C}$, suggesting high thermal stability of SAPO-34 templated by BA. Samples 15 and 22 have TG curves similar to that of Sample 4, and the results of weight loss are listed in Table 6. The number of template molecules per CHA cage were calculated based on the elemental composition and topological structure of SAPO-34, with 1.88, 1.75 and 1.84 BA molecules for Samples 4, 15 and 22, respectively. These values are similar, suggesting little effect from crystallization temperature and synthetic method on the inclusion of the organic amine in SAPO-34. The BA number per cage, which is higher

Table 6

Thermal analysis results of Samples 4,15 and 22.

\begin{tabular}{lccc}
\hline \multirow{2}{*}{ Sample } & \multicolumn{2}{c}{ Weight loss (wt\%) } & \multirow{2}{*}{ Template per cage } \\
\cline { 2 - 3 } & I & II + III & \\
\hline 4 & 0.9 & 15.8 & 1.88 \\
15 & 2.0 & 14.7 & 1.75 \\
22 & 1.8 & 15.3 & 1.84 \\
\hline
\end{tabular}




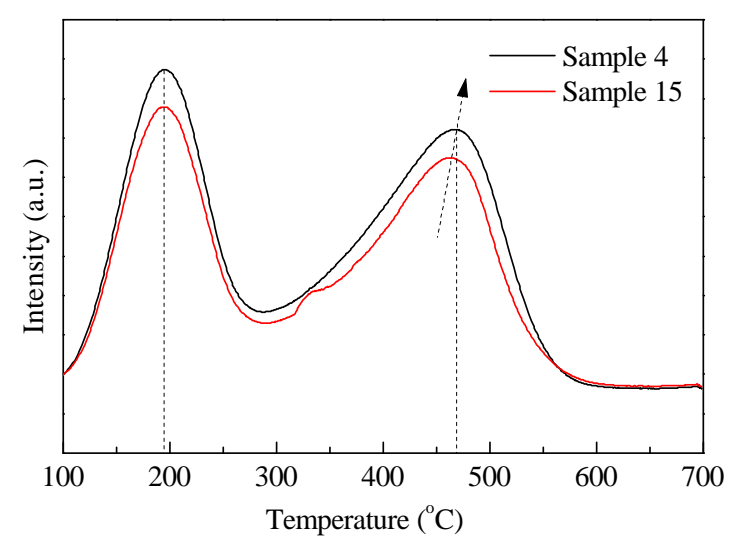

Fig. 6. $\mathrm{NH}_{3}$-TPD curves of Samples 4 and 15.

than that of tetraethylammonium hydroxide (TEAOH) [13] and close to diethylamine (DEA) [17], is reasonable considering the small molecule size of BA. The high number of BA molecules per cage also explains the easy production of SAPO-34-BA with higher Si content, because the organic amine can compensate for a more negative framework charge and thus prompt higher Si incorporation [25].

The ${ }^{29} \mathrm{Si},{ }^{27} \mathrm{Al}$ and ${ }^{31} \mathrm{P}$ MAS NMR spectra were obtained to investigate the local atomic coordination environments in the as-synthesized Sample 4 . The ${ }^{29} \mathrm{Si}$ spectrum is complex because of the high silica content of Sample 4, which consists of five peaks ranging from -91 to $-110 \mathrm{ppm}$ corresponding to $\mathrm{Si}(\mathrm{OSi})_{n}(\mathrm{OAl})_{(4-n)}(n=0-4)$ species, respectively (Fig. 4). The strong peak at -91 ppm suggests a dominant occupation of $\mathrm{Si}(4 \mathrm{Al})$ species in the framework, which is consistent with the higher BA molecule number per cage in the SAPO-34 crystals revealed by TG analysis. This structure can compensate more framework charge and thus facilitate the existence of more single $\mathrm{Si}(4 \mathrm{Al})$ environments.

The ${ }^{27} \mathrm{Al}$ MAS NMR spectrum of Sample 4 displays two peaks centered at around 37 and 9 ppm. The strong resonance at high field should arise from a tetrahedral $\mathrm{Al}$ species, and the weak one is attributed to penta-coordinated Al formed by an additional interaction of one water or template molecule with the framework aluminum. Only one strong resonance peak at 30 ppm can be observed in the ${ }^{31} \mathrm{P}$ spectrum, suggesting a predominant $\mathrm{P}(4 \mathrm{Al})$ environment in the framework.

The acidic properties of Samples 4 and 15 were investigated by $\mathrm{NH}_{3}$-TPD. There are two desorption peaks at about 190-200 and $450-470{ }^{\circ} \mathrm{C}$ for the samples (Fig. 6), corresponding to $\mathrm{NH}_{3}$ desorbed from weak and strong acid sites, respectively. Although both samples have a similar Si content, their acidic properties are different, which is possibly because of the different $\mathrm{Si}$ distribution ( $\mathrm{Si}$ coordination environment) in the crystals [26,27]. Sample 15 , which was synthesized at $240{ }^{\circ} \mathrm{C}$, possesses less acidity than the sample synthesized at $200{ }^{\circ} \mathrm{C}$, demonstrating that the crystallization conditions may exert influence on the acidic properties (Si distribution) of the samples.

\subsection{Catalytic performance}

Monomethylamine (MMA) and dimethylamine (DMA) are important intermediates in chemical industries. These compounds are mainly produced by the methanol amination reaction with amorphous acidic oxide $\left(\mathrm{Al}_{2} \mathrm{O}_{3}\right.$ or $\left.\mathrm{SiO}_{2}-\mathrm{Al}_{2} \mathrm{O}_{3}\right)$ as the catalyst at $390-430{ }^{\circ} \mathrm{C}$ and $\sim 20 \mathrm{~atm}$. Trimethylamine (TMA) is the predominant product because of thermodynamic equilibrium during the process. Small pore molecular sieves with eight-membered rings are promising catalysts for the methanol amination reaction to improve the selectivity for MMA and DMA $[28,29]$.

The catalytic performance of the BA-templated SAPO-34 samples were evaluated in the methanol amination reaction. The steady-state reaction data obtained with Samples 4 and 15 as catalyst at different reaction temperatures were determined after 170 min on stream and listed in Table 7. The dominant amination products were MMA and DMA for both catalysts, and only small amounts of TMA were generated. A higher methanol conversion and lower selectivity for MMA plus DMA was observed for Sample 4 compared with Sample 15 at each reaction temperature. This is possibly because Sample 4 has larger acid sites, which promote the acid catalyzed conversion of reactants and further methylation of products in the methanol amination reaction. The selectivity of MMA plus DMA in the three methylamine products over Sample 15 at $330{ }^{\circ} \mathrm{C}$ was $90.77 \%$. Methanol conversion was greatly improved by raising the reaction temperature to $350^{\circ} \mathrm{C}$, and the selectivity for DMA and TMA increased, implying an enhancement of the methylation degree. The (MMA + DMA) selectivity in the three methylamines presents a slight decline as compared with the results at $330^{\circ} \mathrm{C}$. However, the (MMA + DMA) selectivity in all products is higher than that at $330^{\circ} \mathrm{C}$ because of the decrease of dimethyl ether (DME) in the products. Methanol conversion exceeded $80 \%$ by further raising the reaction temperature to $380{ }^{\circ} \mathrm{C}$. The (MMA + DMA) selectivity drops under these conditions, but is

Table 7

Reaction results for methylamines synthesis using Samples 4 and 15 at TOS = 170 min $^{\text {a }}$.

\begin{tabular}{|c|c|c|c|c|c|c|c|c|c|}
\hline \multirow{2}{*}{ Sample } & \multirow{2}{*}{$T\left({ }^{\circ} \mathrm{C}\right)$} & \multirow{2}{*}{ Conversion (\%) } & \multicolumn{6}{|c|}{ Selectivity (wt\%) } & \multirow{2}{*}{$\left.\operatorname{Sel}_{(M M A}+\mathrm{DMA}\right){ }^{\mathrm{b}}(\mathrm{wt} \%)$} \\
\hline & & & MMA & DMA & TMA & MMA + DMA & DME & $\mathrm{CH}_{4}$ & \\
\hline 4 & 330 & 51.19 & 34.66 & 42.63 & 16.15 & 77.29 & 6.20 & 0.37 & 82.72 \\
\hline 4 & 350 & 71.46 & 29.54 & 47.07 & 18.32 & 76.61 & 4.81 & 0.26 & 80.70 \\
\hline 15 & 330 & 34.43 & 39.02 & 43.86 & 8.43 & 82.88 & 8.12 & 0.57 & 90.77 \\
\hline 15 & 350 & 51.07 & 34.20 & 48.93 & 10.40 & 83.13 & 6.09 & 0.38 & 88.88 \\
\hline 15 & 380 & 82.00 & 26.78 & 54.73 & 14.46 & 81.51 & 3.84 & 0.20 & 84.94 \\
\hline
\end{tabular}

${ }^{\mathrm{a}} \mathrm{NH}_{3} / \mathrm{CH}_{3} \mathrm{OH}$ molar ratio $=2 / 1, \mathrm{WHSV}=0.813 \mathrm{~h}^{-1} .{ }^{\mathrm{b}}(\mathrm{MMA}+\mathrm{DMA})$ selectivity in the three methylamine products. 


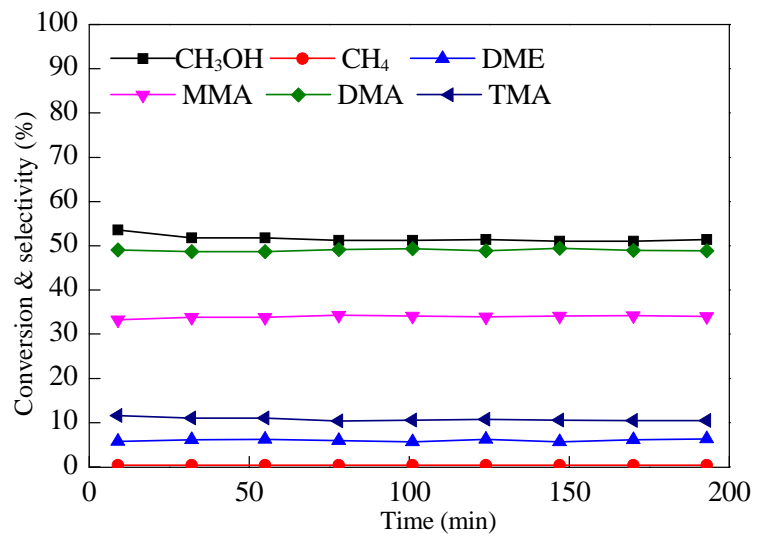

Fig. 7. Methanol conversion and product selectivity in the methanol amination reaction on Sample 15 at $350{ }^{\circ} \mathrm{C}\left(\mathrm{NH}_{3} / \mathrm{CH}_{3} \mathrm{OH}\right.$ molar ratio $=$ $2 / 1$ WHSV $=0.813 \mathrm{~h}^{-1}$ ).

still maintained at a high level (> 80\%). These results suggest that Sample 15 has excellent shape-selective catalytic effect because of the 8-membered windows in the structure of SAPO-34 and its suitable acidic properties. Fig. 7 shows the methanol conversion and selectivity of all products with time using Sample 15 at $350{ }^{\circ} \mathrm{C}$. Methanol conversion and the selectivities of all products are stable in the tested reaction time of 193 min. These preliminary results demonstrate that BA-templated SAPO-34 can be an excellent catalyst for the synthesis of methylamines.

\section{Conclusions}

SAPO-34 has been synthesized by using $n$-butylamine as a templating agent. The silica amount in the initial gel and crystallization temperature have great effect on the synthetic re- sults. Only lamellar AlPO-kanemite was obtained at $160{ }^{\circ} \mathrm{C}$. Pure SAPO-34 was synthesized using a higher silica feeding amount at $200{ }^{\circ} \mathrm{C}$. Investigation of the crystallization process revealed that AlPO-kanemite is generated as an intermediate, which transforms to SAPO-34 under the assistance/participant of silica. SAPO-34 was synthesized with a wider range of silica content by further increasing the crystallization temperature to $240{ }^{\circ} \mathrm{C}$, showing that higher temperature can effectively suppress the generation of lamellar materials. Unlike the crystallization process at $200{ }^{\circ} \mathrm{C}$, no AlPO-kanemite intermediate was observed at $240{ }^{\circ} \mathrm{C}$ and SAPO-34 crystallizes directly from the amorphous gel. We successfully synthesized CHA-SAPO products at $240{ }^{\circ} \mathrm{C}$ by the aminothermal method and found PA a suitable template for the synthesis of SAPO-34. The BA-templated SAPO-34 has good crystallinity, high thermal stability and high $\mathrm{Si}(4 \mathrm{Al})$ content in the framework because of the small size of BA. The as-synthesized SAPO-34 shows excellent shape-selective catalytic performance in the methanol amination reaction with high methanol conversion and good selectivity for MMA and DMA, implying that the BA-templated SAPO-34 has potential as a catalyst for the synthesis of methylamines.

\section{References}

[1] B. M. Lok, C. A. Messina, R. L. Patton, R. T. Gajek, T. R. Cannan, E. M. Flanigen, J. Am. Chem. Soc., 1984, 106, 6092-6093.

[2] B. M. Lok, C. A. Messina, R. L. Patton, R. T. Gajek, T. R. Cannan, E. M. Flanigen, US Patent 4440871, 1984.

[3] J. Liang, H. Y. Li, S. G. Zhao, W. G. Guo, R. H. Wang, M. L. Ying, Appl. Catal., 1990, 64, 31-40.

[4] P. Tian, Y. X. Wei, M. Ye, Z. M. Liu, ACS Catal., 2015, 5, 1922-1938.

[5] Y. Zhou, L. Qi, Y. X. Wei, C. Y. Yuan, M. Z. Zhang, Z. M. Liu, Chin. J. Catal., 2016, 37, 1496-1501.

\section{Graphical Abstract}

Chin. J. Catal., 2017, 38: 574-582 doi: 10.1016/S1872-2067(17)62775-X

\section{SAPO-34 synthesized with $n$-butylamine as a template and its catalytic application in the methanol amination reaction}

Yuyan Qiao, Pengfei Wu, Xiao Xiang, Miao Yang, Quanyi Wang, Peng Tian*, Zhongmin Liu* Dalian Institute of Chemical Physics, Chinese Academy of Sciences; University of Chinese Academy of Sciences
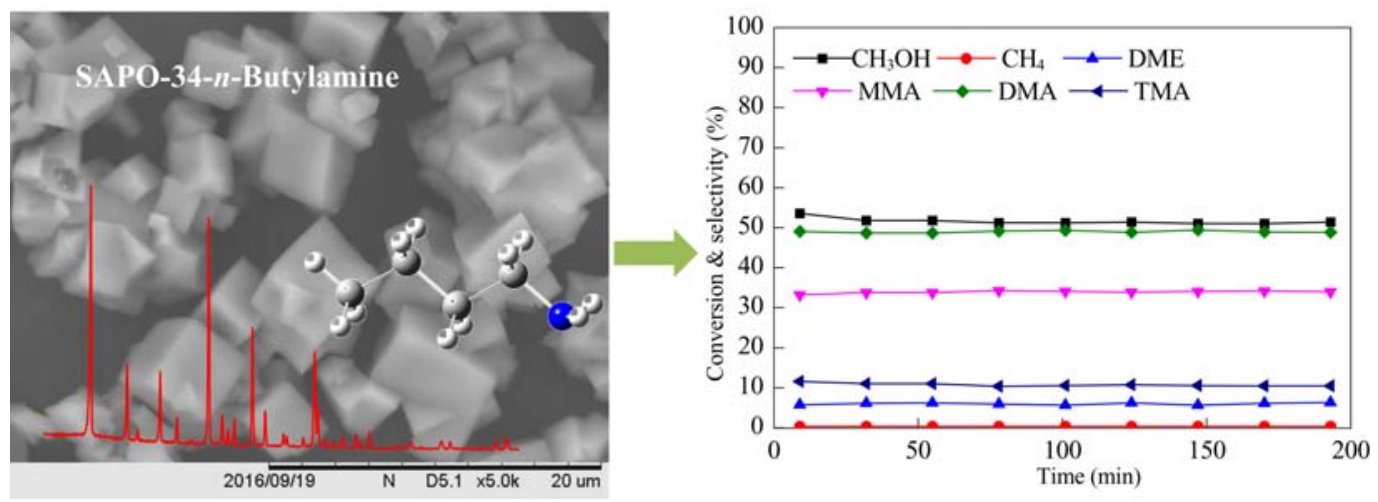

$n$-Butylamine was used as a template to synthesize SAPO-34 with excellent shape-selective catalytic performance in the methanol amination reaction. 
[6] J. J. Li, X. L. Pan, X. H. Bao, Chin. J. Catal., 2015, 36, 1131-1135.

[7] J. Tan, Z. M. Liu, X. H. Bao, X. C. Liu, X. W. Han, C. Q. He, R. S. Zhai. Microporous Mesoporous Mater., 2002, 57, 97-108.

[8] D. Fan, P. Tian, S. T. Xu, Q. H. Xia, X. Su, L. Zhang, Y. Zhang, Y. L. He, Z. M. Liu. J. Mater. Chem., 2012, 22, 6568-6574.

[9] L. Zhang, Y. N. Huang, J. Mater. Chem. A, 2015, 3, 4522-4529.

[10] Y. Y. Jin, Q. Sun, G. D. Qi, C. G. Yang, J. Xu, F. Chen, X. J. Meng, F. Deng, F. S. Xiao, Angew. Chem. Int. Ed., 2013, 52, 9172-9175.

[11] D. Fan, P. Tian, X. Su, Y. Y. Yuan, D. H. Wang, C. Wang, M. Yang, L. Y. Wang, S. T. Xu, Z. M. Liu., J. Mater. Chem. A, 2013, 1, 14206-14213.

[12] M. G. O’Brien, M. Sanchez-Sanchez, A. M. Beale, D. W. Lewis, G. Sankar, C. R. A. Catlow, J. Phys. Chem. C, 2007, 111, 16951-16961.

[13] R. Vomscheid, M. Briend, M. J. Peltre, P. P. Man, D. Barthomeuf, J. Phys. Chem., 1994, 98, 9614-9618.

[14] T. Álvaro-Muñoz, C. Márquez-Álvarez, E. Sastre. Catal. Today, 2012, 179, 27-34.

[15] C. Q. He, Z. M. Liu, L. X. Yang, G. Y. Cai, Chin. J. Catal., 1995, 16, 33-37.

[16] S. Wilson, P. Barger, Microporous Mesoporous Mater., 1999, 29,117-126.

[17] G. Y. Liu, P. Tian, J. Z. Li, D. Z. Zhang, F. Zhou, Z. M. Liu, Microporous Mesoporous Mater., 2008, 111, 143-149.
[18] G. Y. Liu, P. Tian, Z. M. Liu, Chin. J. Catal., 2012, 33, 174-182.

[19] E. Dumitriu, A. Azzouz, V. Hulea, D. Lutic, H. Kessler, Microporous Mater., 1997, 10, 1-12.

[20] A. M. Prakash, S. Unnikrishnan, J. Chem. Soc., Faraday Trans., 1994, 90, 2291-2296.

[21] S. Cheng, J. N. Tzeng, B. Y. Hsu, Chem. Mater., 1997, 9, 1788-1796.

[22] H. O. Pastore, E. C. de Oliveira, G. B. Superti, G. Gatti, L. Marchese, J. Phys. Chem. C, 2007, 111, 3116-3129.

[23] D. H. Wang, P. Tian, M. Yang, S. T. Xu, D. Fan, X. Su, Y. Yang, C. Wang, Z. M. Liu, Microporous Mesoporous Mater., 2014, 194, 8-14.

[24] H. Egged, C. Djerassih, J. Am. Chem. Soc., 1973, 95, 3710-3718.

[25] H. R. Zhao, S. M. Shi, J. X. Wu, Y. Ding, N. Li, Chin. J. Catal., 2016, 37, 227-233.

[26] D. Fan, P. Tian, S. T. Xu, D. H. Wang, Y. Yang, J. Z. Li, Q. Y. Wang, M. Yang, Z. M. Liu, New J. Chem., 2016, 40, 4236-4244.

[27] P. Tian, B. Li, S. T. Xu, X. Su, D. H. Wang, L. Zhang, D. Fan, Y. Qi, Z. M. Liu, J. Phys. Chem. C, 2013, 117, 4048-4056

[28] D. R. Corbin, S. Schwarz, G. C. Sonnichsen, Catal. Today, 1997, 37, 71-102.

[29] H. Y. Jeon, C. H. Shin, H. J. Jung, S. B. Hong, Appl. Catal. A, 2006, 305, 70-78.

\title{
以正丁胺为模板剂合成SAPO-34及其在氨甲基化反应中的应用
}

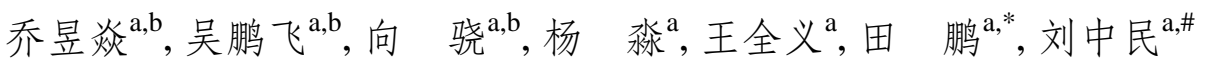 \\ a中国科学院大连化学物理研究所, 甲醇制烯烃国家工程实验室, 辽宁大连 116023 \\ b 中国科学院大学, 北京100039
}

摘要: 以正丁胺为模板剂首次合成了纯相的SAPO-34分子篮. 考察了硅投料量、硅源种类以及晶化温度等条件对所得样品 性质的影响. 发现反应温度为 $200{ }^{\circ} \mathrm{C}$ 时, 不加入硅源, 合成产物为磷酸铝层状相kanemite; 加入硅溶胶后, 产物中开始有 SAPO-34晶体出现, 且随着硅投料量的增加, kanemite逐渐消失, SAPO-34分子篮成为主要产物, 最终在 $\mathrm{SiO}_{2} / \mathrm{Al}_{2} \mathrm{O}_{3}$ 摩尔比为 0.6-1.4时得到纯相的SAPO-34. 不同的硅源对 SAPO-34产品的形貌和尺寸影响较大. 反应温度为 $160{ }^{\circ} \mathrm{C}$ 时, 合成体系中无 法晶化得到SAPO-34, 当提高至 $240^{\circ} \mathrm{C}$ 后, 由于层状相在高温下不能稳定存在, 此时可以在较宽的硅投料区间内合成得到纯 相SAPO-34产品. 在 200 和 $240^{\circ} \mathrm{C}$ 时, 考察了使用同样的初始凝胶合成SAPO-34样品的晶化过程. 发现在 $200{ }^{\circ} \mathrm{C}$ 时, 合成体 系中最初大量生成了 kanemite, 随后逐渐减少, SAPO-34晶体开始生成并最终成为唯一产物. 而在 $240{ }^{\circ} \mathrm{C}$ 时, 无机原料很快 被溶解, 之后大量的SAPO-34晶体快速生成, 产物的收率和相对结晶度迅速增加, 且整个晶化过程中并无层状相生成. 这再 次证明了高温对层状相的生成有着明显的抑制作用, 因此提高晶化温度可以成为一种有效调节产品晶相的方法, 特别是在 容易产生层状相杂质的合成体系中. 鉴于胺热合成方法的诸多优点, 例如较高的收率、较好的吸附分离及催化反应效果, 几种伯胺(正丁胺、正丙胺、环己胺)被用于充当模板剂和溶剂来合成得到了SAPO分子笁产品. 其中, 正丙胺为一种新的合 成SAPO-34的模板剂. 对SAPO-34产品进行X射线衍射、X射线荧光分析、扫描电镜、 $\mathrm{N}_{2}$ 物理吸附、 $\mathrm{NH}_{3}$ 程序升温脱附、 热重和固体核磁共振等表征. 结果显示, 得到的SAPO-34产品具有很好的结晶度、孔结构以及合适的酸性. 使用氨甲基化 反应对正丁胺合成的SAPO-34进行催化反应评价. 结果显示, 该样品对甲胺和二甲胺具有很高的择形选择性, 是一种具有 潜在前景的甲胺合成催化剂.

关键词: SAPO-34分子笁; 正丁胺; 伯胺; 合成; 高温; 氨甲基化反应

收稿日期: 2016-11-28. 接受日期: 2016-12-25. 出版日期: 2017-03-05.

*通讯联系人. 电话: (0411)84379218; 传真: (0411)84691570; 电子信箱: tianpeng@dicp.ac.cn

\#通讯联系人. 电话: (0411)84379998; 传真: (0411)84691570; 电子信箱: liuzm@dicp.ac.cn

基金来源：国家自然科学基金(21676262, 21476228, 21506207); 中国科学院前沿科学重点研究项目(QYZDB-SSW-JSC040).

本文的英文电子版由Elsevier出版社在ScienceDirect上出版(http://www.sciencedirect.com/science/journal/18722067). 